\title{
University human resources management mechanism innovation exploration and research
}

\author{
Lan Yang ${ }^{1}$ \\ ${ }^{1}$ Management Science and Engineering School, \\ China University Of Geosciences Great Wall College, \\ Baoding, China
}

\begin{abstract}
-with the advent of the era of knowledge economy, colleges and universities of human resources management is facing new challenges, only to constantly innovation,can improve their strength. This paper first introduces the background and necessity of the university human resources management mechanism innovation. Then, from recruitment configuration of human resource management, training development, performance management, etc to explore management mechanism innovation.
\end{abstract}

Keywords- human resources; Management mechanism; innovation

\section{Introduction}

The knowledge economy era, human resource in promoting the economic development and social progress of the role is becoming increasingly prominent. Advantages of human resources will become the ultimate competitive advantage.How to build a scientific, efficient, standard system, human resources management mechanism and maximize the overall effectiveness of human resources, has become one of the management problems to be solved. The university is the main base of national knowledge innovation and cultivate the spirit of innovation, and innovation is an important cradle of talent, which is also a main source of a high-level creative talents. Institutions of higher learning, too, should improve the quality of human resources, developing human resources, to improve the competitiveness of colleges and universities. Human resources in colleges and universities depends largely on the improvement of the

\author{
Xiao-Xian $\mathrm{Lv}^{2}$ \\ ${ }^{2}$ Academic Affairs Division, \\ China University Of Geosciences Great Wall College, \\ Baoding, China
}

overall quality level and the mechanism of human resource management. But in current human resource management mode of the present situation and the existence of certain problems, hindering the overall development of human resources in colleges and universities and the improvement of teachers' overall quality. Therefore, comprehensive and thorough reform of university human resources management mode, is the trend of The Times. Therefore, innovation of the university human resources management mechanism plays a very important practical significance.

2.The necessity of university human resources management mechanism innovation

The university human resources management mechanism innovation requirements, mainly reflected in following aspects:

(1) The development of colleges and universities has increasingly become a sign of comprehensive national strength. Reviewing the development of human beings, the development of institutions of higher learning fits the development of country ,and the development of colleges and universities is a basic synchronization and almost a sign of the country and regional prosperity. Important role in the process of the development of colleges and universities in the country, without a large number of professionals with higher education training, without science and technology innovation talent reserves, it is impossible to gain or maintain power. Great university should meet the unknown world, explore the objective truth, which will provide a scientific basis for human to solve the major 
problem facing front,and it also should be the knowledge innovation, promoting the transformation of scientific and technological achievements to real productivity. The development of institutions of higher learning has increasingly become a sign of comprehensive national strength.

(2) human resource management has increasingly become the guarantee of the development of colleges and universities. Human resource is the first resource of the economic and social which plays an important role in promoting the economic development and social progress. Bear an important task of talent cultivation, knowledge innovation and social service in colleges and universities,and plays an important role in the social life. Colleges and universities depends on the quality of talent training, talent resources overall quality of human resources in colleges and universities depends on the level of human resource management. Therefore, how to make a reasonable allocation of human resources in colleges and universities, arouse people's enthusiasm and creativity, in the personnel management work in colleges and universities to bring into the new concept of human resource management, more fully to excavate the potential of people,which has important significance to make the human resources management of colleges and universities to adapt to the society, teachers' quality to adapt to the discipline construction in colleges and universities .

(3) The innovation of university human resources management mechanism has increasingly become the core of the internal management of institutions of higher learning. Although in recent years in human resources management mechanism in colleges and universities has made breakthrough progress, the introduction of competition, innovation mode and the construction of teachers team construction has been constantly improving, etc. Colleges and universities teacher human resource management mechanism is still the main problem of colleges and universities to create a high-level university. To conduct the thorough research to the innovation of colleges and universities teacher human resource management mechanism, its aim is to build a vibrant, colleges and universities with Chinese characteristics of human resource management system, creating a lively and energetic talents growth environment,which can make every teacher in objective compatible with my knowledge and ability of intelligence played on jobs, for knowledge innovation, scientific research and social service. So, innovative university human resources management mechanism,and improve overall quality, not only the important content of higher education reform and development requires,but also is the inevitable requirement of higher education to adapt to social and economic development.

\section{Innovation of university human resources management mechanism}

Human resources management innovation mechanism in colleges and universities, only in order to realize the school staff development and comprehensive service strategy and at the same time, the dilution pipe reinforcement, fade out laws to strengthen the rule of law as the prerequisite conditions, to set up effectively. This paper studies the five aspects contains the human resources management recruitment, training and development, performance management, compensation management and selection of promotion.

(1) the innovation of university human resources management recruitment mechanism

Recruitment in terms of money, to set up special funds, increase investment in recruitment work. In determining job vacancies, first, to make an scientific analysis of the personnel vacancies or to add. Should be determined through the investigation and analysis, to define each department and unit, the number of personnel for personnel management of related rules and regulations as well as the measurement analysis method, through scientific analysis method and standard of work system to clear. Make full use of external hires and internal recruiting the two main channel. To scientific design the hiring process, enhance the selection rate of people who conforms to 
the requirements. In order to shorten the recruitment period,before administrative ability in written, on the one hand, written examination and interview the seamless docking, on the other hand, after the completion of the interview and professional ability test, calculate the comprehensive scores as soon as possible.Evaluate the effect of recruitment,according to recruitment, recruitment costs and time employment rate, these three aspects.

(2)Innovation of Training and development of university human resources management and the mechanism

Training and development as the most important means and measures to promote an organizational effectiveness and productivity, is the requirement of one organization personnel to achieve the sustainable development. In terms of training demand analysis, generally needs to carry on from organization,work and staff,these three aspects. In the planning of the training,lack of overall planning of training work, therefore, human resource management department should according to established the human resources management strategy, make training rules and the annual training plan, to determine the various training programs to undertake units or departments, training funds support scope and objects, the training input lines of the project, to complete the relevant training programs and related content. To facilitate faculty flexible use of time to study, should make full use of network information technology, online learning system is established. Training effect evaluation should include training goal, the trainee satisfaction and inspection on the whole training process and summarize successful experience and problems of training the gap.

(3) Innovation of Performance management of university human resources management mechanism

Performance plan as the basic link of employee performance management system stated, it means a management process that managers and employees to discuss, to achieve the goal of communication, responsibility, method. Mainly includes formulating the specific performance of the implementation plan, performance targets and performance evaluation index. To strengthen and improve the link of the work , first, the human resource management department is responsible for the overall plan for the performance management work, making good performance management work plan. Second, each year after school work points, ask for each department according to the school work points revised department or unit of work plans, and on this basis, work out the departments and units of each post performance targets and performance evaluation indicators. Performance implementation is focused on the performance evaluation of data collection and the counseling and communication of implementation process. Data collecting of faculty performance evaluation,adopting to, recording, sampling method, evaluation method and other methods,bring the work performance, work ability and work attitude into the scope of employee performance evaluation data collection. Performance appraisal is focused on to choose a suitable evaluation methods. Suggest to adopt to 360 - degree feedback evaluation method, project evaluation method and evaluation method of critical incident method to the management personnel, and not the members of teacher and those logistics hillock personnel of technical post. Performance to improve the performance effect in the application of the stage, mainly to the performance evaluation results and rewards are tied to the vital interests such as salary, promotion, only in this way can make the performance management to exert the real power. Performance improvement stage, mainly for the various problems of the performance management work, carries on the deep reason, looking for measures to further improve the performance management of the key actions.

(4)Innovation of compensation mechanism of human resource management in colleges and universities

On the salary management system, to ensure the 
reasonable and scientific compensation system, should follow a set of complete and formal salary management process. 1. The establishment of the compensation principles and strategies should make a careful analysis of the current school strategy development model and development direction and development stage. Also give full consideration to the school staff values and compensation requirement and other internal factors and social environment, economy and political environment and other external factors. 2. Job analysis and evaluation can be adopted relatively popular model of Hay and CRG in the international to conduct a comprehensive evaluation of position. Job grade sequences are obtained. 3. The relevant professional institutions entrusted to survey the same size or the same type of compensation level and structure of investigation in university, to solve the problem of compensation of external competitiveness. 4. Compensation design is mainly for schools relatively to the local market and competitors payed their own compensation levels, which can take the cost leadership strategy, market lead policy,the policy of market followers and fixed-salary strategy.5. The implementation and correction of compensation system, mainly refers to make payroll, check, pay, communicate and adjust, etc. During the real pay calculation,only one who is likely to cause mistakes in operation and it is very difficult to find and correct errors in time. Therefore, we suggest that the human resource management department should also set the professional to check and supervise, and minimize the error of paying.

(5) The innovation of selective and promotional university human resources management mechanism

In terms of selective and promotional path, first, hold down the post belonged to the series. Second, improve the standard professional and technical skills and those logistics work selected the promotion to the transformation mechanism of management work. Professional technical post is selected to promote to management work, compensation in accordance with the cash positions at the same level, but the position degradation employment, incorporated into the management work. Third, refine management post series in different positions and types of promotion channels. Manage the different positions for the series of segments, such as financial assets management, student management, human resource management and so on.There are totally 8 class management job by principle the selection and promotion of its position in the category of management job .

\section{Conclusion}

The era of knowledge economy, colleges and universities only adhere to the people-oriented, and strengthen the innovation of human resource management mechanism, to constantly meet the new challenges. Based on the analysis of the human resources management of colleges and universities,according to the basis of the background and necessity of mechanism innovation, from recruitment, training and development, performance management, salary management and selection of ascending,these five aspects put forward the countermeasures of management mechanism innovation.

\section{Reference}

[1] Xing Zhouling. The human resource management on organizational performance [D].Nanchang university, 2009.

[2] Cai xu-dong. Beijing sports university human resources management mechanism innovation research [D]. Beijing sport university, 2013.

[3] $\mathrm{Li}$ zhen-hai.The research of human resource management in colleges and universities in the new era [D]. Northwest university, 2004.

[4] Hai Jie. Colleges and universities teacher human resource management research [D]. Tianjin normal university, 2004.

[5] Ren Zhonghui. University human resources management mechanism innovation question research [D]. Xi 'an university of science and 
technology, 2005.

[6] Xie Fang. University human resources management incentive mechanism research [D]. Tianjin university, 2002.

[7] Ai xiao-ping. The current colleges and universities teacher human resource management research in China [D]. Central China normal university, 2006.

[8] Li Juan. Hubei university human resources management present situation and countermeasure research [D]. Wuhan textile university, 2013.

[9] Yang Feng. Shaanxi province university human resources management research [D]. Xi 'an university of technology, 2007. 